\title{
Dualisme Kewenangan Pemeriksaan Dugaan Pelanggaran Kode Etik Notaris
}

\author{
Muhammad Khalid \\ Program Kenotariatan Fakultas Hukum Universitas Islam Indonesia \\ Jl. Cik Di Tiro No. 1 Yogyakarta \\ pascahukumuii@yahoo.com
}

\begin{abstract}
Problems in the study: first, the dualism of authority checks Notary alleged violations of the code of conduct? Second, the authority checks the code of conduct by the Regional Supervisory Council based on the code of ethics? This research is empirical jurisdiction. The study concluded, first, the Regional Supervisory Council and the WCA Board may conduct an examination of the alleged violations of the code etik Notaris. Regional Supervisory Council code etik Notaris checks if the report from the public and there is also a certain criteria of Notaries code violations that can be checked by the Supervisory Council of Regions. Honorary Board area is not just waiting for reports received, but can process it if it finds violations of the code of conduct, if the Honorary Board of the Regional found violations of the Code, the Honor Council will call a notary in question to be fostered, because the function of the Honorary Council of Regions in addition to overseeing the code of conduct, there is pembianaan also against the Notary. Code violations that have been reported to the Regional Supervisory Council can not be diverted report to the Council of Honor, and vice versa. Secondly, the provision of the code of conduct by the inspection authority Regional Supervisory Council is not in accordance with the characteristics of the code of professional conduct.
\end{abstract}

Keywords: Regional Supervisory Council, Notary.

\begin{abstract}
Abstrak
Permasalahan dalam penelitian ini: pertama, dualisme kewenangan pemeriksaan dugaan pelanggaran kode etik Notaris? Kedua, kewenangan pemeriksaan kode etik oleh Majelis Pengawas Daerah berdasarkan kode etik profesi? Penelitian ini merupakan penelitian yuridis empiris. Hasil penelitian menyimpulkan, pertama, Majelis Pengawas Daerah dan Dewan Kehormatan dapat melakukan pemeriksaan terhadap dugaan pelanggaran kode etik Notaris. Majelis Pengawas Daerah melakukan pemeriksaan kode etik Notaris jika adanya laporan dari masyarakat dan tidak ada juga kriteria tertentu dari pelanggaran kode etik Notaris yang dapat diperiksa oleh Majelis Pengawas Daerah. Dewan Kehormatan Daerah tidak hanya menunggu laporan yang masuk, namun bisa memprosesnya apabila menemukan pelanggaran kode etik, apabila Dewan Kehormatan Daerah menemukan pelanggaran Kode Etik, maka Dewan Kehormatan akan panggil notaris yang bersangkutan untuk dibina, karena fungsi Dewan Kehormatan Daerah selain mengawasi kode etik, ada juga pembianaan terhadap Notaris. Pelanggaran kode etik yang sudah dilaporkan kepada Majelis Pengawas Daerah tidak bisa dialihkan laporannya kepada Dewan Kehormatan, begitu juga sebaliknya. Kedua, pemberian kewenangan pemeriksaan kode etik oleh Majelis Pengawas Daerah tidak sesuai dengan karakteristik kode etik profesi.
\end{abstract}

Kata-kata Kunci: Majelis Pengawas Daerah, Notaris. 


\section{Pendahuluan}

Perkembangan masyarakat telah mengalami peningkatan yang sangat pesat, khususnya di bidang perekonomian. Dalam setiap transaksi kehidupan manusia membutuhkan adanya sebuah kepastian hukum untuk sebuah perlindungan atas dirinya. Perlindungan tersebut didapatkan dari Pemerintah sebagai pihak yang berkewajiban melindungi setiap masyarakatnya. Cara Pemerintah beragam dalam melindungi masyarakatanya, mulai dari memberikan keamanan dengan kepastian hukum tersebut sehingga masyarakat pun mempunyai rasa percaya dan merasa aman untuk melakukan tindakan atau peristiwa hukum.

Kewajiban Notaris dalam membuat akta harus tetap berpegang pada ketentuan undang-undang sehingga akta yang dibuat oleh atau dihadapan dapat memberikan perlindungan hukum bagi para pihak dalam pembuatan suatu perjanjian. Notaris melindungi kliennya sehingga posisi mereka seimbang dan tidak ada yang dirugikan, serta memberikan kepastian hukum kepada kliennya apabila terjadi wanprestasi terhadap perjanjian yang disepakati. Terutama dalam hal pembuktian suatu perjanjian tersebut harus ada bukti yang otentik salah satunya dengan akta notaris. Berdasarkan Pasal 1 ayat (6) UUJN-P bahwa akta notaris adalah akta yang dibuat oleh atau dihadapan Notaris menurut bentuk dan tata cara yang ditetapkan dalam undang-undang tersebut. Akta notaris harus memberikan kepastian hukum bahwa akta yang dibuatnya sesuai dengan prosedur dalam pembuatan akta dan berdasarkan keterangan para pihak yang menghadap saat itu ${ }^{1}$.

Masyarakat membutuhkan seseorang yang berkompeten dalam bidangnya dan dapat memberikan kepastian hukum serta perlindungan hukum sehingga dengan begitu meningkat pula kebutuhan jasa notaris dan jumlah notaris di dalam masyarakat secara linear, maka dibutuhkan juga pengawasan terhadap profesi ini guna menjaga supaya notaris dapat menjalankan profesinya sesuai dengan peraturan perundang-undangan dan Kode Etik Notaris.

Kode Etik Notaris merupakan kaidah moral yang wajib ditaati oleh setiap anggota perkumpulan untuk menjaga kehormatan dan keluhuran jabatan. Notaris dibebankan tanggung jawab dan etika profesi sehingga notaris tersebut dapat menjalankan tugas dan jabatannya dengan sungguh-sungguh. Kesalahan yang sering terjadi pada notaris sering kali disebabkan oleh keteledoran notaris itu sendiri, serta bujukan-bujukan yang terkait dengan 126.

${ }^{1}$ Habib Adjie, Menjalin Pemikiran-Pendapat Tentang Kenotariatan, PT Citra Aditya Bakti, Surabaya, 2013, hlm. 
honorarium yang tinggi sehingga mengesampingkan etika seorang Notaris. Seorang Notaris dalam menjalankan kewenangannya bertanggung jawab terhadap diri sendiri dan kepada masyarakat. Bertanggung jawab kepada diri sendiri bahwa notaris berkerja karena integritas moral, intelektual dan profesional sebagai bagian dari kehidupan. Salah satu kepentingan yang terkait dalam kehidupan profesi apabila terjadi penyimpangan kewenangan notaris yaitu kepentingan klien².

Peran Notaris dalam masyarakat sangatlah penting, sehingga diperlukan adanya pengawasan. Pengawasan tersebut bertujuan untuk meminimalisir terjadinya kesalahan yang dilakukan oleh Notaris terhadap kepentingan klien yang menggunakan jasanya. Habib Adjie berpendapat bahwa tujuan pengawasan terhadap Notaris ketika menjalankan tugas jabatannya harus memenuhi semua persyaratan berkaitan pelaksanaan tugas jabatan Notaris demi kepentingan masyarakat yang dilayaninya ${ }^{3}$. Tujuan lain pengawasan terhadap Notaris adalah Notaris dihadirkan untuk melayani kepentingan masyarakat yang membutuhkan alat bukti berupa Akta Otentik sesuai permintaan bersangkutan kepada Notaris, sehingga tanpa adanya masyarakat yang membutuhkan Notaris maka Notaris tidak ada gunanya ${ }^{4}$.

Pengawasan terhadap Profesi Notaris merupakan kewenangan dari Menteri Hukum dan Hak Asasi Manusia, dalam Pasal 67 ayat (1) UUJN mengatakan pengawasan terhadap Notaris dilakukan oleh Menteri. Pasal 67 ayat (2) UUJN mengakatakan bahwa dalam menjalankan pengawasan Menteri menbentuk Majelis Pengawas Notaris. Pasal 68 UndangUndang Nomor 30 Tahun 2004 Tentang Jabatan Notaris mengatakan yang dimaksud Majelis Pegawas adalah Majelis Pengawas Daerah, Majelis Pengawas Wilayah dan Majelis Pengawas Pusat. Majelis Pengawas ini di bentuk dengan maksud agar mempermudah kinerja Menteri Hukum dan Hak Asasi Manusia sebagai lembaga yang mengawasi kinerja Notaris.

Berdasarkan Pasal 1 ayat (6) UUJN-P, Majelis Pengawas Notaris adalah suatu badan yang mempunyai kewenangan dan kewajiban untuk melaksanakan pembinaan dan pengawasan terhadap notaris. Untuk menjalankan fungsi pengawasan yang dilakukan oleh Majelis Pengawas Notaris maka telah disusun peraturan perundang-undangan yang mengatur tentang tugas, wewenang dan kewajiban Mejelis Pengawas Notaris dengan

\footnotetext{
${ }^{2}$ Liliana Tedjosaputro, Etika Profesi Notaris Dalam Penegakan Hukum Pidana, Bigraf Publishing, Yogyakarta,1994, hlm. 43. $h \operatorname{lm} 3$.

${ }^{3}$ Habib Adjie, Majelis Pengawas Notaris Sebagai Pejabat Tata Usaba Negara, Refika Aditama, Bandung, 2011, ${ }^{4}$ Ibid, hlm 3.
} 


\section{LEX Renaissance No. 1 VOL. 2 JANUARI 2017: 35 - 48}

Undang-Undang Nomor 2 Tahun 2014 tentang Perubahan Atas Undang-Undang Nomor 30 Tahun 2004 Tentang Jabatan Notaris. Kemudian Peraturan Menteri Hukum dan Hak Asasi Manusia Republik Indonesia Nomor M.02.PR08.10 Tahun 2004 Tentang Tata Cara Pengangkatan Anggota, Pemberhentian Anggota, Susunan Organisasi Tata Cara Kerja dan Tata Cara Pemeriksaan Majelis Pengawas Notaris, dan Keputusan Menteri Hukum dan HAM Republik Indonesia Nomor: M.39-PW.07.10 Tahun 2004 tentang Pedoman Pelaksanaan Tugas oleh Majelis Pengawas Notaris.

Bedasarkan Pasal 70 huruf a UUJN, Majelis Pengawas Daerah berwenang menyelanggarakan sidang untuk memeriksa adanya dugaan pelanggaran kode etik Notaris atau pelanggaran pelaksanaan jabatan Notaris. Sedangkan berdasarkan Perubahan Anggaran Dasar Ikatan Notaris Indonesia Pasal 12, Dewan Kehormatan juga diberi kewenangan memeriksa atas dugaan pelanggaran ketentuan kode etik Notaris. Kewenangan yang lahir kepada Majelis Pengawas Daerah adalah perintah UUJN, sedang kewenangan yang lahir kepada Dewan Kehormatan adalah perintah Anggaran Dasar Organisasi Notaris yaitu Ikatan Notaris Indonesia yang selanjutnya disinggkat INI.

\section{Rumusan Masalah}

Berdasarkan latar belakang yang diuraikan diatas, maka permasalahan dalam penelitian ini dapat dirumuskan sebagai berikut: pertama, bagaimana dualisme kewenangan pemeriksaan dugaan pealanggaran kode etik Notaris? Kedua, apakah kewenangan pemeriksaan kode etik oleh Majelis Pengawas Daerah sudah sesuai dengan karakteristik kode etik profesi?

\section{Tujuan Penelitian}

Pertama, untuk mengetahui dualisme kewenangan pemeriksaan dugaan pelanggaran kode etik Notaris. Kedua, untuk mengetahui pemeriksaan kode etik oleh Majelis Pengawas sudah sesuai dengan karakteristik kode etik profesi.

\section{Metode Penelitian}

Metode yang digunakan dalam penelitian ini adalah yuridis normatif. Bahan yang digunakan dalam penelitian ini adalah menggunakan data primer dan data sekunder, yaitu: a. Data primer yang merupakan data yang diperoleh langsung dari responden terkait objek penelitian; b. Data sekunder terdiri dari bahan hukum primer, skunder dan tersier, bahan hukum primer yakni bahan hukum yang mengikat, meliputi peraturan perundang - 
undangan yang berlaku. Sedangkan bahan skunder merupakan bahan hukum yang erat kaitannya dengan bahan hukum primer dan dapat membantu serta memahami bahan hukum primer berupa semua publikasi tentang hukum yang bukan dokumen resmi, yang terdiri dari buku - buku literatur mengenai hukum pada umumnya dan hukum bisnis pada khususnya, serta jurnal - jurnal hukum. Serta bahan tersier merupakan bahan hukum primer dan sekunder seperti bahan - bahan non hukum, misalnya kamus. Metode pendekatan yang dipergunakan dalam membahas masalah penelitian ini adalah metode pendekatan yuridis empiris. Dalam hal ini pendekatan yuridis digunakan untuk menganalisa berbagai peraturan tentang jabatan Notaris, sedangkan pendekatan empiris dipergunakan untuk menganalisis hukum yang dilihat dari perilaku masyarakat dalam kehidupan bermasyarakat, selalu berinteraksi dan berhubungan dengan aspek kemasyarakatan. ${ }^{5}$ Setelah data - data tersebut terkumpul akan diinventarisasi kemudian diseleksi sesuai untuk digunakan menjawab pokok permasalahan penelitian ini. Selanjutnya dianalisa secara kualitatif untuk mencapai kejelasan masalah yang akan dibahas. Data tersebut dianalisis secara deskriptif kualitatif, yakni data tersebut digambarkan dan ditata secara sistematis dalam wujud uraian - uraian kemudian diambil maknanya sebagai pernyataan dan kesimpulan. Penggunaan metode analisis kualitatif.

\section{Hasil Penelitian dan Pembahasan}

\section{Dualisme Kewenangan Pemeriksaan Dugaan Pelanggaran Kode Etik Notaris}

Notaris memiliki tugas mengatur secara tertulis dan otentik hubungan hukum antara para pihak yang secara mufakat meminta jasa Notaris. Pentingnya Notaris dalam kehidupan masyarakat khususnya dalam pembuatan akta otentik yang digunakan sebagai alat bukti, maka Notaris mempunyai kedudukan sebagai pejabat umum yang berwenang membuat akta otentik dan sekaligus merupakan perpanjangan tangan pemerintah.

Secara administratif, Notaris memiliki hubungan dengan negara dalam hal pemerintahan. Salah satunya adalah berkaitan dengan pengangkatan dan pemberhentian Notaris. Menurut Komar Andasasmita, bentuk atau corak Notaris dapat dibagi menjadi 2 (dua) kelompok utama yakni6:

1. Notariat functional, hal mana wewenang-wewenang pemerintah didelegasikan (gedelegeerd) dan demikian itu diduga mempunyai kebenaran isinya, mempunyai kekuatan bukti formal dan mempunyai daya/kekuatan eksekusi. Di negara-negara yang

5Bambang Sunggono,Metodologi Penelitian Hukum, Jakarta: PT Raja Grafindo Persada, 2003, hlm. 43.

${ }^{6}$ Komar Andasasmita, Notaris I, Bandung: Sumur, 1984., hlm 12 
menganut bentuk notariat ini terdapat pemisahan yang keras antara wettelijke dan nietwetteljike, wekzaamheden yaitu pekerjaan-pekerjaan yang didasarkan undangundang/hukum dan yang tidak/bukan dalam notariat.

2. Notariat Profesional, dalam kelompok ini walaupun pemerintah mengatur tentang organisasinya tetapi akta - akta Notaris ini tidak mempunyai akibat - akibat khusus tentang kebenarnya, kekuatan bukti demikian kekuatan eksekutorialnya.

Sebagai konsekuensi logis sering dengan adanya tanggung jawab Notaris kepada masyrakat, maka haruslah dijamin adanya pengawasan dan pembinaan terus menerus agar Notaris selalu sesuai dengan kaidah hukum yang mendasari kewenangnnya dan dapat terhindar dari penyalahgunaan kewenangan atau kepercayaan yang diberikan. Agar nilai nilai etika dan hukum yang seharusnya dijunjung tinggi oleh Notaris dapat berjalan sesuai undang - undang yang ada, maka sangat diperlukan adanya pengawasan.

Pengawasan adalah proses pengamatan dari pelaksanaan seluruh kegiatan organisasi untuk menjamin agar supaya semua pekerjaan yang sedang dilaksanakan berjalan sesuai dengan rencana yang telah ditentukan sebelumnya ${ }^{7}$. Adapun tujuan tujuan pegawasan Notaris adalah memenuhi persyaratan - persyratan dan menjalankan tugasnya sesuai dangan ketentuan - ketentuan dalam perundang - undangan yang berlaku demi kepentingan masyrakat umum, karena Notaris dihadirkan untuk melayani kepentingan masyarakat yang membutuhkan alat bukti berupa akta otentik sesuai permintaan kepada Notaris.

Majelis Pengawas Daerah sebagai lembaga yang mengawasi Notaris memiliki wewenang bedasarkan Pasal 70 huruf a UUJN, menyelanggarakan sidang untuk memeriksa adanya dugaan pelanggaran kode etik Notaris atau pelanggaran pelaksanaan jabatan Notaris. Sedangkan berdasarkan Anggaran Dasar Ikatan Notaris Indonesia Pasal 12, Dewan Kehormatan juga diberi kewenangan memeriksa atas dugaan pelanggaran ketentuan kode etik Notaris. Kewenangan yang lahir kepada Majelis Pengawas Daerah adalah perintah UUJN, sedang kewenangan yang lahir kepada Dewan Kehormatan adalah perintah Anggaran Dasar Organisasi Notaris yaitu Ikatan Notaris Indonesia.

Berdasarkan penjelasan tersebut telah terjadi pelimpahan keweangan yang sama kepada 2 (dua) lembaga pengawas Notaris. H. M. Firdaus Ibnu Pamungkas, S.H, sebagai ketua Majelis Pengawas Daerah dan ketua Dewan Kehormatan Daerah Kota Yogyakarta mengatakan bahwa ${ }^{8}$, implementasi pemeriksaan kode etik oleh Majelis Pengawas Daerah dilakukan jika adanya laporan dari masyarakat, setelah itu dibentuk Majelis Pemeriksa Daerah untuk memeriksa dugaan pelanggaran kode etik tersebut.

\footnotetext{
${ }^{7}$ Sujamto, Aspek-Aspek Pengawasan di Indonesia, Jakarta: Sinar Grafika, 1987, hlm. 53.

${ }^{8}$ Hasil wawancara dengan Notaris/PPAT M. Firdauz Ibnu Pamungkas pada tanggal 29 November 2016.
} 
Pemeriksaan kode etik bisa dilakuan oleh Majelis Pengawas Daerah dan Dewan kehormatan Daerah, dalam implementasinya Dr. Hendrik Budi Untung Surya Bekti, S.H.,M.M. sebagai sekretaris Majelis Pengawas Daerah kota Yogyakarta mengatakan bahwa $^{9}$, tidak ada juga kriteria tertentu dari pelanggaran kode etik Notaris yang hanya diperiksa oleh Majelis Pengawas Daerah, jadi jika memang adanya laporan pelanggaran kode etik akan diperiksa oleh Majelis Pengawas Daerah. Pelanggaran kode etik yang sudah dilaporkan kepada Majelis Pengawas Daerah tidak bisa di alihkan laporannya kepada Dewan Kehormatan, begitu juga sebaliknya.

Hendrik Budi Untung mengatakan bahwa Majelis Pengawas Daerah tidak berwenang untuk menjatuhkan sanksi apapun. Meski berwenang untuk menerima laporan dari masyrakat dan Notaris lainya dan melaporkan hasil sidang dan pemeriksaanya kepada pihak yang melaporkan, Notaris yang bersangkutan, Majelis Pengawas Wilayah, Majelis Pengawas Pusat dan Organisasi Notaris (INI).

Firdauz Ibnu Pamungkas menambahkan bahwa ${ }^{10}$, Penjatuhan sanksi oleh Majelis Pengawas Notaris berbeda dengan penjatuhan sanksi oleh Dewan Kehormatan Daerah, Majelis Pengawas Wilayah berwenang memberikan sanksi teguran lisan dan tertulis, dan mengusulkan pemberhentian sementara 3 (tiga) bulan sampai dengan 6 (enam) bulan dan pemberhentian dengan tidak hormat kepada Majelis Pengawas Pusat. Selanjutnya Majelis Pengawas Pusat menjatuhkan sanksi pemberhentian sementara dan mengusulkan pemberhentian tidak hormat kepada Menteri Hukum dan Hak Asasi Manusia. Namun jika Dewan Kehormatan berwenang memberikan sanksi teguran, peringatan, pemberhentian sementara dari anggota perkumpulan, pemberhentian dengan hormat dari keanggotaan perkumpulan, pemberhentian dengan tidak hormat dari anggota perkumpulan dan meberikan rekomendasi disertai usulan pemecatan sebagai Notaris kepada Menteri Hukum dan Hak Asasi Manusia.

Jika dilihat dari sanksi yang di berikan oleh 2 (dua) lembaga pengawas tersebut, Firdauz Ibnu Pamungkas berpendapat bahwa ${ }^{11}$, sanksi yang diberikan oleh Dewan Kehormatan tidaklah efektif karena jika hanya dikeluarkan dari perkumpulan, maka Notaris tetap bisa menjalankan kegiatannya seperti biasa, hanya saja jika nanti ingin mengajukan perpindahan wilayah kerja, baru menemui hambatan.

\footnotetext{
${ }^{9}$ Hasil wawancara dengan Notaris/PPAT Hendrik Budi Untung pada tanggal 3 Januari 2017

${ }^{10}$ Hasil wawancara dengan Notaris/PPAT M. Firdauz Ibnu Pamungkas pada tanggal 29 November 2016

${ }^{11}$ Hasil wawancara dengan Notaris/PPAT M. Firdauz Ibnu Pamungkas pada tanggal 29 November 2016
} 
Firdauz Ibnu Pamungkas juga mengatakan bahwa ${ }^{12}$ Dewan Kehormatan Daerah dalam melakukan pemeriksaan kode etik tidak hanya menunggu laporan yang masuk, namun bisa memprosesnya apabila menemukan pelanggaran kode etik, jika adanya laporan yang masuk maka akan dilanjutkan dengan pemeriksaan oleh Dewan Kehormatan Daerah. Apabila Dewan Kehormatan Daerah menemukan pelanggaran Kode Etik, maka Dewan Kehormatan akan panggil notaris yang bersangkutan untuk dibina agar tidak melanggar kode etik kembali, karena fungsi Dewan Kehormatan Daerah selain mengawasi kode etik, ada juga pembianaan terhadap Notaris.

Firdauz Ibnu Pamungkas berpendapat bahwa ${ }^{13}$ kewenangan pemeriksaan kode etik Notaris sebaiknya tetap seperti sekarang yaitu bisa di periksa oleh Dewan Kehormatan Daerah dan Majelis Pengwas daerah. Pemeriksaan kode etik oleh Majelis Pemeriksa Daerah adalah perintah dari UUJN. Firdauz juga tidak setuju jika kewenangan pemeriksaan Kode etik tersebut tidak dilakukan oleh Dewan Kehormatan Daerah karena dengan adanya kewenangan tersebut Dewan Kehormatan Daerah dapat lebih aktif berperan dalam menegakkan kode etik Notaris. Hendrik Budi Untung juga setuju dengan adanya kewenangan pemeriksaan kewenangan oleh Dewan Kehormatan Daerah dan Majelis Pengwas daerah, karena peran Majelis Pengwas Daerah sebagai lembaga yang mengawasi Notaris tidak hanya menjalankan perintah UUJN dan UUJN - P, tapi juga kode etik Notaris ${ }^{14}$.

\section{Kewenangan Pemeriksaan Kode Etik Oleh Majelis Pengawas Daerah}

Profesi notaris adalah suatu profesi hukum yang dituntut bukan hanya memiliki kemampuan teknis, melainkan juga kemampuan untuk menentukan sikap berdasarkan pengetahuan yang mendalam tentang hukum dan maknanya serta ada kerelaan untuk menanamkan kesadaran hukum dalam masyarakat. Seorang Notaris mesti juga bermoral, sehingga dalam hal ini diperlukan suatu kode etik yang ditetapkan sendiri oleh pelaku profesi sehingga menjadi beban kewajiban bagi dirinya sendiri agar selalu dilaksanakan dalam keadaan apapun. Kode etik adalah kompas yang menunjuk arah moral bagi profesional hukum dan sekaligus menjamin mutu moral profesi hukum dimata masyrakat. ${ }^{15}$

Kode etik profesi hukum dapat berubah dan diubah seiring dengan perkembangan ilmu pengetahuan dan teknologi sehingga angota kelompok profesi hukum tidak akan ketinggalan zaman. Kode etik profesi merupakan hasil pengaturan diri profesi yang

\footnotetext{
${ }^{12}$ Hasil wawancara dengan Notaris/PPAT M. Firdauz Ibnu Pamungkas pada tanggal 29 November 2016

${ }^{13}$ Hasil wawancara dengan Notaris/PPAT M. Firdauz Ibnu Pamungkas pada tanggal 29 November 2016

${ }^{14}$ Hasil wawancara dengan Notaris/PPAT Hendrik Budi Untung pada tanggal 3 Januari 2017

${ }^{15}$ E.Y. Kanter, Etika Profesi Hukum Jakarta: Stori Grafika, 2001 hlm,113
} 
bersangkutan dan perwujudan nilai moral yang hakiki yang tidak bisa dipakasakan dari luar. Kode etik profesi berlaku effektif jika dijiwai oleh cita - cita dan nilai - nilai yang hidup dalam lingkungan profesi itu sendiri sehingga kode etik dapat menjadi tolak ukur perbuatan anggota profesi serta upaya pencegahan berbuat yang tidak etis bagi anggotanya. ${ }^{16}$

Kode etik memiliki manfaat yaitu ${ }^{17}: 1$.Kode etik menjadi tempat perlindungan bagi anggotanya manakala berhadapan dengan persaingan yang tidak sehat dan tidak jujur; 2 . Kode etik menjamin rasa solidaritas dan kolegialitas antar anggota untuk saling menghormati; 3. Kode etik memngokohkan ikatan persaudaraan di antara para anggota, terutama bila menghadapi campur tangan pihak lain; 4. Kode etik menuntun anggotanya untuk memiliki kualitas pengetahuan hukum; 5. Kode etik mewajibkan anggotanya untuk mendahulukan pelayanan kepada anggotanya. Kode etik juga memiliki beberapa fungsi yaitu : 1. Sebagai sarana kontrol social; 2. Sebagai pencegah campur tangan pihak lain; 3. Sebagai pencegah kesalahpahaman dan konflik.

Kode etik merupakan sesuatu yang penting dalam suatu profesi hukum guna menjamin tidak terjadinya konflik antara sesama profesi dan juga menjadi sarana untuk masyarakat untuk mengetahui apakah anggota kolompok profesi telah memenuhi kewajiban profesionalnya. Kode etik merupakan hasil "self regulation" dari organisasi itu sendiri sehingga dalam hal pembuatan kode etik maupun dalam hal penegakan kode etik seharusnya dilakukan oleh organisasi itu sendiri.

Notaris sebagai profesi hukum juga memiliki kode etik yang dibuat oleh organisasi Notaris yaitu INI. Kode etik Notaris pertama kali diputuskan di Surabaya pada Tahun 1974. ${ }^{18}$ Setelah itu terus mengalami perubahan sampai terakhir adalah Kongres Luar Biasa Ikatan Notaris Indonesia, di Banten, 29 - 30 Mei 2015. Berdasarkan Pasal 82 UUJN - P, INI merupakan organisasi tunggal Notaris di Indonesia sehingga INI dalam hal ini berhak untuk membuat kode etik dan menegakkan kode etik sesuai perintah Pasal 83 UUJN. Upaya penegakan kode etik ini dilakukan dengan membuat lembaga Dewan Kehormatan yang berfungsi untuk kontrol terlaksananya kode etik di lapangan internal perkumpulan.

Secara formal Dewan Kehormatan merupakan alat perlengkapan Perkumpulan sebagai suatu badan atau lembaga yang bebas dan mandiri, Dewan Kehormatan bertugas untuk melakukan pembinaan, bimbingan, pengawsaan, pembenahan anggota dalam

${ }^{16}$ Abdul Kadir Muhammad , Etika Profesi Hukum, Bandung: Biography Publising, 2001. hlm, 77

${ }^{17}$ E.Y. Kanter, op, cit., hlm. 115

18 Pengurus Pusat Ikatan Notaris Indonesia, Jati Diri Notaris Indonesia dulu, sekarang dan Masa Depan, Gramedia Pustaka, Jakarta, 2008 hlm, 198 


\section{LEX Renaissance No. 1 VOL. 2 JANUARI 2017: 35 - 48}

menjunjung tinggi kode etik dan juga memeriksa dan mengambil keputusan atas dugaan pelanggaran kode etik.

Posisi Dewan Kehormatan sangat strategis karena dipundaknya tersemat amanah untuk memastikan para Notaris memahami dan melaksanakan kode etik. Oleh karena itu INI membentuk sistem berjenjang dalam organisasi Dewan Kehormatan. Dewan Kehormatan dibangun di tingkat Kabupaten/Kota, Propinsi dan Pusat. Pasal 12 ayat (2) Dewan Kehormatan berwenang memeriksa dan mengambil keputusan atas dugaan pelanggaran kode etik Notaris. Dewan Kehormatan Daerah adalah unsur pelaksana yang penting karena berinteraksi langsung dengan Notaris dan pihak yang mengetahui duduk perkara pelanggaran kode etik pertama kalinya. Dewan Kehormatan Daerah harus menjadi institusi yang pertama kali mengetahui adanya dugaan pelanggaran kode etik yang dilakukan oleh oknum Notaris tertentu.

Namun, di luar Dewan Kehormatan sebagai alat kelengkapan Organisasi, Notaris juga memiliki badan Pengawas lain, yaitu Majelis Pengawas Notaris. Pada dasarnya kewenangan melakukan pengawasan dan pemeriksaaan terhadap Notaris adalah Menteri Hukum dan Hak Asasi Manusia yang dalam pelaksanaannya menteri membentuk Majelis Pengawas Notaris. Dengan demikian kewenangan pengawasan terhadap Notaris ada pada Pemerintah, sehingga berkaitan dengan cara pemerintah memperoleh wewenangan tersebut.

Ada 2 (dua) cara utama untuk memperoleh wewenang pemerintah, yaitu Atribusi dan Delegasi. Atribusi merupakan pembentukan wewenang tertentu dan pemberiannya kepada organ tertentu atau juga dirumuskan pada atribusi terjadi pemberian wewenang pemerintahan yang baru oleh suatu ketentuan dalam peraturan perundang - undangan. Atribusi pembentukan atau pemberian wewenang pemerintah didasarkan aturan hukum yang dapat dibedakan asalanya, yakni yang asalanya dari pemerintah tingkat pusat bersumber dari Majelis Permusyawaratan rakyat (MPR), Undang - Undang Dasar (UUD), atau Undang - undang dan yang asalnya dari pemerintah daerah bersumber dari Dewan Perwakilan Rakyat Daerah (DPRD) atau Peraturan Daerah (Perda). Atribusi wewenang dibentuk atau dibuat atau diciptakan oleh aturan hukum yang bersangkutan atau atribusi ditentukan aturan hukum yang menyebutkan didalamnya. ${ }^{19}$

Delegasi merupakan pelimpahan suatu wewenang yang telah ada oleh badan atau Jabatan TUN yang telah memperoleh suatu wewenang pemerintah secara atributif kepada badan atau jabatan TUN lainnya. Dalam rumusan lain bahwa delegasi sebagai penyeraahan

${ }^{19}$ Habib Adjie, Sekilas Dunia Notaris \& PPAT Indonesia, Mandar Maju, Bandung, 2009, hlm. 90. 
wewenang oleh pejabat pemerintah (Pejabat TUN) kepada pihak lain dan wewenang tersebut menjadi tanggung jawab pihak lain tersebut. Dengan ada kemungkinan bahwa badan atau Jabatan TUN dapat mendelegasikan wewenangnya (delegans) kepada badan atau Jabatan yang bukan TUN ( delegataris). Suatu delegasi selalu selalu didahului oleh adanya suatu atribusi wewenang. Badan atau Jabatan TUN yang tidak mempunyai atribus wewenang tidak dapat mendelegasikan wewenangnya kepada pihak lain. ${ }^{20}$

Berdasarkan pengertian tersebut, wewenang untuk melakukan pengawasan terhadap Notaris secara atributif ada pada Menteri sendiri, yang dibuat, diciptakan dan diperintahkan dalam Undang -undang sebagaimana pasal 67 ayat (1) UUJN. Kedudukan Menteri dalam menjalankan kekuasaan pemerintah dalam kualifikasi sebagai Badan atau Jabatan TUN. Berdasarkan Pasal 67 ayat (2) UUJN menteri mendelegasikan wewenang pengawasan tersebut kepada badan dengan nama Majelis Pengawas. Pasal 1 ayat (1) Peraturan Menteri Hukum dan Hak Asasi Manusi M.02.Pr.08.10 Tahun 2004, Majelis Pengawas adalah suatu badan yang mempunyai wewenang dan kewajiban untuk melaksanakan pengawasan dan pembinaan terhadap Notaris. Dengan demikian dapat disimpulakan bahwa menteri selaku delegans dan Majelis Pengawas selaku delegataris yang memiliki wewenang mengawasi Notaris sepenuhnya, tampa perlu untuk mengembalikan wewenangnya kepada delegans.

Pasal 68 UUJN menyatakan bahwa Majelis Pengawas dalam menjalankan tugasnya terdiri atas: a. Majelis Pengawas Daerah; b. Majelis Pengawas Wilayah; c. Majelis Pengawas Pusat.

Majelis Pengawas Daerah adalah pengawas utama bagi Notaris dalam menjalankan tugasnya, hal ini dikarenakan Majelis Pengawas Daerah adalah pengawas pertama yang akan melakukan pemerikasaan jika ada Notaris yang melanggar ketentuan dalam UUJN maupun kode etik Notaris. Pasal 70 huruf a UUJN menyatakan bahwa Majelis Pengawas Daerah berwenang untuk menyelenggarakan sidang untuk memeriksa adanya dugaan pelanggaran kode etik Notaris atau pelanggaran pelaksanaan jabatan Notaris. Namun Majelis Pengawas Daerah hanya berwenang untuk memeriksa dugaan adanya pelanggaran kode etik atau pelanggaran pelaksanaan jabatan Notaris, tidak berwenang untuk memngambil keputusan tersebut. Kewenangan pengambilan keputusan tersebut ada pada Majelis Pengawas Wilayah dan Majelis Pengawas Pusat. 
Berdasarkan penjelasan diatas maka kewenangan pemerikasaan dugaan pelanggaran kode etik notaris dapat dilakukan oleh alat kelengkapan organisasi yaitu Dewan Kehormatan dan Majelis pengawas Daerah. Namun, Pemeriksaan dugaan pelanggaran oleh Majelis Pengawas Daerah bertentangan dengan perintah pasal 83 Angka 1 (satu) UUJN yang menyatakan bahwa organisasi Notaris menetapkan dan menegakan kode etik Notaris. Sehingga dalam hal ini hanya Dewan Kehormatan saja yang seharusnya diberi kewenangan untuk memeriksa dugaan pelanggaran kode etik Notaris.

Kode Etik profesi dapat berfungsi sebagaimana mestinya maka paling tidak ada dua syarat yang mesti dipenuhi. Pertama, Kode Etik itu harus dibuat oleh profesi itu sendiri, Kode Etik tidak akan efektif, kalau diterima begitu saja dari atas, dari instansi pemerintah atau instansi lain, karena tidak akan dijiwai oleh cita-cita dan nilai-nilai yang hidup dalam kalangan profesi itu sendiri. Kedua, agar Kode Etik berhasil dengan baik adalah bahwa pelaksanaannya diawasi terus-menerus ${ }^{21}$.

E. Sumaryono menyatakan dalam konteks profesi, kode etik memiliki karakteristik antara lain ${ }^{22}$ : a. Merupakan produk Etika Terapan, sebab dihasilkan berdasarkan penerapan pemikiran etis atas suatu profesi tertentu; b. Kode etik dapat berubah dan diubah seiring dengan perkembangan IPTEK, sehingga sering menimbulkan penyalahgunaan yang meresahkan masyarakat dan membingungkan profesi itu sendiri; c. Kode etik tidak berlaku efektif bila keberadaannya di-“drop” begitu saja dari atas (yaitu pemerintah atau instansi lain) sebab tidak akan dijiwai oleh cita - cita dan nilai - nilai yang hidup dalam kalangan profesi itu sendiri; d. Kode etik merupakan hasil "self regulation" (pengaturan diri) dari profesi itu sendiri. Ini dimaksudkan untuk mewujudkan nilai - nilai moral yang dianggap hakiki, yang pada prinsipnya tidak pernah dapat paksaan dari luar; e. Tujuan utama dirumuskan kode etik adalah untuk mencegah terjadinya prilaku yang tidak etis, oleh karnanya : kode etik sering berisikan ketentuan wajib lapor tentang pelanggarannya.

Pemberian kewenangan pemeriksaan kode etik oleh Majelis Pengawas Daerah tidak sesuai dengan karakteristik kode etik profesi. Hal ini disebabkan Majelis Pengawas daerah tidaklah sepenuhnya mengerti nilai dan cita - cita kode etik Notaris. Anggota Majelis Pengawas Daerah terdiri dari unsur akademisi, pemerintah, dan Notaris. Namun Dewan Kehormatan sebagai pengawas Notaris yang di bentuk oleh organisasi Notaris, terdiri dari unsur Notaris seluruhnya, sehingga paham akan semangat nilai dan cita - cita kode etik yang dibuat oleh Notaris sendiri.

${ }^{21}$ K. Bertens, Etika, Gramedia Pustaka Utama, Jakarta, 1997, hlm. 282 - 283
${ }^{22}$ E.Sumaryono, Etika Profesi Hukum, Kanisius, Yogyakarta,1995, hlm. 147. 


\section{Penutup}

Penelitian ini menyimpulkan, pertama: Majelis Pengawas Daerah dan Dewan Kehormatan dapat melakukan pemeriksaan terhadap dugaan pelanggaran kode etik Notaris. Majelis Pengawas Daerah melakukan pemeriksaan kode etik Notaris jika adanya laporan dari masyarakat dan tidak ada juga kriteria tertentu dari pelanggaran kode etik Notaris yang dapat diperiksa oleh Majelis Pengawas Daerah. Dewan Kehormatan Daerah tidak hanya menunggu laporan yang masuk, namun bisa memprosesnya apabila menemukan pelanggaran kode etik, apabila Dewan Kehormatan Daerah menemukan pelanggaran Kode Etik, maka Dewan Kehormatan akan panggil notaris yang bersangkutan untuk dibina, karena fungsi Dewan Kehormatan Daerah selain mengawasi kode etik, ada juga pembianaan terhadap Notaris. Pelanggaran kode etik yang sudah dilaporkan kepada Majelis Pengawas Daerah tidak bisa dialihkan laporannya kepada Dewan Kehormatan, begitu juga sebaliknya. Kedua, pemberian kewenangan pemeriksaan kode etik oleh Majelis Pengawas Daerah tidak sesuai dengan karakteristik kode etik profesi. Hal ini disebabkan Majelis Pengawas daerah tidaklah sepenuhnya mengerti nilai dan cita - cita kode etik Notaris. Anggota Majelis Pengawas Daerah terdiri dari unsur akademisi, pemerintah, dan Notaris. Namun Dewan Kehormatan sebagai pengawas Notaris yang di bentuk oleh organisasi Notaris, terdiri dari unsur Notaris seluruhnya, sehingga paham semangat nilai dan cita - cita kode etik yang dibuat oleh Notaris sendiri. Peneliti menyarankan, pertama: kewenangan pemeriksaan kode etik Notaris seharusnya diberikan kepada Dewan Kehormatan agar bisa berjalan efektif dan Majelis Pengawas Daerah hanya melakukan pemeriksaan pelanggaran Undang - Undang Jabatan Notaris saja. Kedua, meninjau ulang sanksi yang diberikan oleh Dewan Kehormatan agar bisa menimbulkan efek jera terhadap pelanggar kode etik Notaris. Ketiga, Organisasi Notaris (INI) memberikan saran kepada pemerintah, dalam hal ini Menteri Hukum dan Hak Asasi Manusia untuk melakukan pelimpahan kewenangan pemeriksaan kode etik hanya kepada Dewan Kehormatan.

\section{Daftar Pusaka}

\section{Buku}

Adjie, Habib Menjalin Pemikiran-Pendapat Tentang Kenotariatan, PT Citra Aditya Bakti, Surabaya, 2013.

, Majelis Pengawas Notaris Sebagai Pejabat Tata Usaha Negara, Refika Aditama, Bandung, 2011.

, Sekilas Dunia Notaris \& PPAT Indonesia, Mandar Maju, Bandung, 2009. 
Andasasmita, Komar, Notaris I, Sumur, Bandung, 1984.

Bertens, K., Etika, Gramedia Pustaka Utama, Jakarta, 1997.

Kanter, E.Y., Etika Profesi Hukum Stori Grafika, Jakarta, 2001.

Muhammad, Abdul Kadir, Etika Profesi Hukum, Biography Publising, Bandung, 2001.

Narbuko, Cholid dan H. Abu Achmadi, Metodologi Penelitian, PT. Bumi Aksara, Jakarta, 2002.

Pengurus Pusat Ikatan Notaris Indonesia, Jati Diri Notaris Indonesia dulu, sekarang dan Masa Depan, Jakarta: Gramedia Pustaka, 2008.

Sujamto, Aspek-Aspek Pengawasan di Indonesia, Sinar Grafika, Jakarta, 1987.

Sunggono, Bambang Metodologi Penelitian Hukum, PT Raja Grafindo Persada, Jakarta, 2003.

Sumaryono, E., Etika Profesi Hukum, Kanisius, Yogyakarta, 1995.

Tedjosaputro, Liliana, Etika Profesi Notaris Dalam Penegakan Hukum Pidana, Bigraf Publishing, Yogyakarta, 1994.

\section{Peraturan Perundang - undangan}

Undang-Undang Nomor 30 Tahun 2004 Tentang Jabatan Notaris.Lembaran Negara Republik Indonesia Tahun 2004 Nomor 117 dan Tambahan Lembaran Negara Republik Indonesia Nomor 4432.

Undang-Undang Nomor 2 Tahun 2014 Tentang Perubahan Atas Undang-Undang Nomor 30 Tahun 2004 Tentang Jabatan Notaris.Lembaran Negara Republik Indonesia Tahun 2014 Nomor 3 dan Tambahan Lembaran Negara Republik Indonesia Nomor 5491.

Kode Etik Notaris Ikatan Notaris Indonesia (I.N.I.) 